\title{
Detection of Deceptive Speech Acts in Chinese Courtroom Trials
}

\author{
Zhanghong $\mathrm{Xu}^{1} \& \mathrm{Xin} \operatorname{Tian}^{2}$ \\ ${ }^{1,2}$ School of English for International Business, Guangdong University of Foreign Studies, Guangzhou, China \\ Correspondence: Zhanghong Xu, No. 2, Baiyun Avenue (N), Baiyun District, School of English for International \\ Business, Guangdong University of Foreign Studies, Guangzhou, China. E-mail: 1458975262@qq.com
}

Received: June 13, 2018 Accepted: July 8, 2018 Online Published: July 28, 2018

doi:10.5539/ijel.v8n6p22 URL: https://doi.org/10.5539/ijel.v8n6p22

\begin{abstract}
Confronted with a trial, litigants tend to focus on disputed facts, and when their interests are threatened they may resort to deceptive statements in order to obtain a judgment in their favor. Making deceptive statements in the court, referred to in this paper as deceptive speech acts (henceforth, DSA), will affect court's judgment, waste judicial resources and harm social justice. Therefore, detection of deceptive speech acts (henceforth, DDSA) is of considerable forensic interests in improving efficiency of courtroom trials and enforcing the authority of legal system. Based on seven authentic cases of Chinese courtroom trials, this study attempts to find out reliable linguistic deception indicators in Chinese courtroom context and establish a model of DDSA. As one of efficient cues to deception, linguistic manipulation enables liars to take deception strategies (i.e., concealment, falsification and distortion). Drawing on the notion of linguistic manipulation, a coding scheme is established, which shows that deception strategies are principally realized by six linguistic indicators (vagueness, generality, intensifiers, formulaic expressions, references to the other, and minimizing markers). Linguistic analyses are made to present how DDSA is achieved in each extract. This research sheds light on data-based studies on DDSA, and offers implications for other judicial practices, like police interrogations, and prosecutor's questioning.
\end{abstract}

Keywords: deceptive speech acts, Chinese courtroom trials, linguistic indicators

\section{Introduction}

Deception, a central characteristic of human life (Granhag \& Stromwall, 2004), is a successful or unsuccessful deliberate attempt, without forewarning, to create in another a belief which the communicator considers to be untruthful (Vrij, 2008). In courtroom trials, litigants conceal or falsify some facts for their own benefits, for they might receive no or slight punishment when they lie or commit perjuries in court. This behavior, defined as DSA, harms judicial system and social justice and integrity. Thus, detection of deceptive speech acts (henceforth, DDSA) will help improve efficiency of courtroom trials and enforce the authority of legal system, and to achieve the above goal, a feasible DDSA model needs constructing for judicial practices.

Studies on motives behind deception, factors stimulating deception and deception detection are carried out in diverse fields, inter alia, psychology, communication, management, and linguistics. With regard to the motives behind deception, while some researchers (Goffman, 1959; Lindskold \& Walters, 1983) insist that people deceive for benefiting others or/and themselves, other scholars posit that people lie for ( i) making a good impression on others or protect self from embarrassment or refusal; (ii) obtaining benefits; (iii) avoiding punishments; (iv) benefiting others; and (v)coordinating social relations (Utz, 2005; Arcimowicz, Cantarero, \& Soroko, 2015; Santibáñez, 2017). As for factors incurring deception, individual differences (like personality) are found to have great impact on people's deceptive behavior (Azizli, Atkinson, Baughman, Chin, \& Harris, 2015; Gylfason, Halldorsson, \& Kristinsson, 2016). For instance, people who have antisocial personality disorder are more inclined to deceive. (Niesten, Nentjes, Merckelbach, \& Bernstein, 2015). Relationships between senders and receivers (friends or strangers) and communication channels (text or face-to-face) also exert great effect on sender's propensity to deceive, receiver's truth-bias and his or her ability to detect (Van Swol \& Braun, 2014; Van Swol, Braun, \& Malhotra, 2012).

Understandings about motives behind deception and factors influencing deception lay a solid foundation for the study of deception detection. CMCA (Criteria-Based Content Analysis) and RM (Reality Monitoring), two well-known tools, are found useful in detecting deception from speaker's statements, with the former one 
frequently employed in criminal investigation (Kohnken, 2004). CMCA hypothesizes that a speaker's account is based on genuine personal experience and the truth-teller is able to incorporate certain types of content into his or her statements. According to RM, truth-tellers are able to show their feelings and provide contextual information, while liars who narrate imagined events are likely to do more planning and reasoning. Linguists have discerned inguistic cues in deceptive statements, which are manifested by more linguistic ambiguity, more references to the other, more negative attitude (Dilmon, 2008), more explicit action verbs, less linguistic complexity and less inferential coherence (Bedwell, Gallagher, Whitten, \& Fiore, 2011). Other scholars attempt to study deception in more details, only to find that liars use fewer fillers such as "um" in deceptive statements (Arciuli, Mallard, \& Villar, 2009).

Experiments on deception detection are conducted by scholars in most previous studies; however, the performance of lab liars and that of real-world liars are not quite consistent, and some detection methods may not work even though distracted variables are carefully controlled. Moreover, previous studies show that detection of deception is so complex that methods from different fields should be integrated to make the detection more accurate.

Though deception detection is a hot topic across different fields around the world, few Chinese scholars tackle the issue of deception, especially in a specific context except one study conducted by Chen and Xu (2013), who investigated the identification of deceptive speech acts in Chinese civil courtroom from pragmatics perspective. However, most Chinese linguists mainly focus on the property of deceptive message from the perspectives of cognition (Zhang, 2008; Cao, 2009) and pragmatics (He \& Zhang, 2004). Therefore, it is of great significance to study deception in Chinese courtroom setting based on authentic Chinese data, which will not only contribute to the academic field, but also benefit judicial practices, providing judicial professionals with detailed descriptions of how defendants manipulate their language and how those deceptive speech acts are detected.

The aim of this article is to find out what linguistic deception indicators can be used to significantly identify DSA in the context of Chinese courtroom trials. This article will be organized as follows: after introducing methodology and data collection in section 2, section 3 will present a coding scheme and explain how it is established. Section 4 will then apply those linguistic indicators in the coding scheme and make a detailed linguistic analysis of the data. Section 5 will draw a conclusion.

\section{Methodology and Data Collection}

In order to analyze linguistic indicators of deception in courtroom trials, we have collected seven cases from Chinese courtroom trials online (Note 1) and Trial Scene (Note 2). Data cover different types of criminal cases, including three bribery cases (A1, A2, A3) and four drug related cases (B1, B2, B3 and B4). Through our pilot study, we find that deceptive statements in the two types of cases are more likely to be discerned. Descriptions of each case can be found in the Appendix.

According to Chinese Criminal Law, whether or not the defendant takes his action intentionally and knowingly is the key element in determining his crimes. Generally speaking, defendants in bribery cases would try to cover up their act of "trading power for money" and describe their behavior as reasonable and obligatory whereas defendants in drug trafficking cases would make excuses for their involvement in the deal.

After investigating the occurrence of deceptive statements in different types of cases, we watch videos carefully and concentrate attention on deceptive cues. As transcription by hand is lengthy and time-consuming, only these conversations, which probably comprise of deceptive statements, are transcribed according to the commonly accepted conventions for transcription. Moreover, news reports about the cases are reviewed to make the analyses more reliable and convincing. The transcriptions in Chinese are translated into English by one researcher, and then the English version of the transcriptions is checked and revised by the other researcher, and finally two researchers have jointly made every effort to guarantee the accuracy of translation.

\section{Designing the Framework for Deception Detection: The Coding Scheme}

According to Rakefet (2008) and Swol, Braun and Malhotra (2012), cues to deception are classified into two kinds: linguistic manipulations (strategic cues), and emotional and cognitive functions (non-strategic cues). As emotional and cognitive functions are rather subtle and complicated, this scheme only concerns itself with linguistic manipulations (strategic cues). Linguistic manipulation is further divided into three categories of deception strategy, each being realized by different linguistic indicators. These preliminary linguistic indicators, chosen on the basis of theoretical considerations and literature review, have been given operational definitions in the linguistic analysis section. This coding scheme is then modified and refined when more linguistic indicators are discovered. The following two subsections will introduce deception strategies that liars employ, and present 
linguistic deception indicators which were tested as efficient in previous research.

\subsection{Deception Strategies}

The widely-known deception strategies are falsification, exaggeration, concealment, omission, equivocation and distortion (Buller, Burgoon, White, \& Ebesu 1994; Bachler, 1995; Galasinski, 2000). As scholars make classifications about deception strategies according to diverse criteria, these classifications are far from clear and sometimes they may overlap. According to linguistic data collected in this article, concealment, falsification and distortion are regarded as three principal deception strategies in Chinese courtroom trials. While falsification is a way of telling a non-existent story, concealment is a way of providing part of the fact but hiding relevant information, and distortion presents the fact with changed intensity. More specifically, if propositional content of the fact is regarded as $p$, then falsification means - $p$, concealment contains part of $p$ and distortion includes p' ("'," means the change of the strength or scope). Linguistic deception indicators are also classified according to its extent to which a fact is presented.

\subsubsection{Concealment}

Concealment, considered as one of deception strategies (Buller, Burgoon, White, \& Ebesu, 1994; Ekman, 1985), is a way of withholding information, usually with ample opportunities to plan the deceit (Buller, Burgoon, White, \& Ebesu, 1994). Concealment can be achieved through vagueness and generalized words. For example, though the defendant in Extract 1 denies offering help to the briber, vagueness “我印象中” (in my impression) makes the information vague and uncertain, thus receivers (the judge, the prosecutor) fails to get the accurate information whether or not the defendant offers help. Generalized words such as “朋友” (friends) in extract 4 are used as excuses for not paying the borrowed money back in bribery cases or for participating in a drug transporting crime.

\subsubsection{Falsification}

Falsification, as one of deception strategies (Buller, Burgoon, White, \& Ebesu, 1994; Galasinski, 2000), falsely attributes a particular statement to the receiver. (Galasinski, 2000). "Reference to the other" and "intensifiers" are two typical manifestations of falsification in that they are used to falsify the fact and misrepresent the information. For example, in the section of linguistic analysis, the defendant in extract 16 makes an excuse for his failure to pay back "the borrowed money" because the lender said that he did not need the money for urgent use. But the borrower's statements testify that the lender didn't say what the defendant stated, and knew that the money lent to the defendant would never come back. Thus it is quite obvious that the defendant makes up an excuse. As for intensifiers, in extract 6 , faced with objective evidence of bank transfer record, which shows that the defendant indeed transferred the money to his partner, the defendant just repeats intensifiers “百分之百”(one hundred percent sure) and “绝对 (definitely)" to deny the criminal acts he actually committed.

\subsubsection{Distortion}

Distortion, taken as one of deception strategies by Galasinski (2000), refers to the utterance through which the speaker does not lie but overstates or minimizes. It consists in changing the strength or scope of the propositions made in the misrepresented utterances. Minimizing markers and formulaic expressions can be used to distort facts. The defendant in extract 12 admits the fact that he plays a role in real estate development, but mitigates his role through minimizing markers, i.e., “协调” (coordinate) and “讲过” (mention). As for formulaic expressions in extract 11, the defendant admits the fact that he helps to support the district with 150,000 yuan but makes an excuse by saying that it is his responsibility to do so. Thus, distortion becomes a way of rationalizing the criminal behavior.

\subsection{Linguistic Indicators}

Scholars have found reliable linguistic indicators to differentiate between factual and deceptive statements (Bedwill et al., 2010; Dulaney \& Earl, 1982; Dilmon, 2008; Johnson \& Raye, 1981; Sorning, 1989; Van Swol 2012, 2014; Yang, 2012). They identified seven proposed linguistic indicators of deception: (1) conditional sentences; (2) vagueness; (3) generality; (4) intensifiers; (5) formulaic expressions; (6) references to the other; and (7) minimizing markers. Broadly speaking, the first five indicators mainly help realize concealment strategies. Indicator (6) substantiates falsification strategies in that deceptive speakers distance themselves from their responsibility and present a fabricated story, whereas Indicator (7) helps realize distortion strategy because minimization weakens the deceptive speaker's role in an event. In our data, indicator (1) "conditional sentences" is not very salient linguistic indicator and will be dropped from consideration in our analysis, and thus we'll make linguistic analyses based on 6 indicators and explore strategies and motives behind each DDSA. It is worth noting that this classification is not fixed, and three deception strategies may be realized by any one of the 
linguistic markers. The coding scheme, which comprises of deception strategies and linguistic indicators, is shown in Table 1.

Table 1. Linguistic indicators for deception examination

\begin{tabular}{lll}
\hline Cues to deception & Deception strategies & Linguistic indicators \\
\hline Linguistic manipulation & Concealment & Vagueness \\
& & Generality \\
& Falsification & Intensifiers \\
& Distortion & References to the other \\
& & Minimizing markers \\
& Formulaic expressions \\
\hline
\end{tabular}

\subsubsection{Concealment}

(1)Vagueness: Vagueness is the use of words whose meaning does not provide a precise description of events (Dilmon, 2008), e.g., maybe, I guess and sort of. It is a part of linguistic hedges which lacks of commitment to a statement or declaration (Bachenko, Fitzpatrick, \& Schonwetter, 2008). According to Yang (2012), vagueness can make uncertain the source of information, i.e., “听说”(hear about), “据我所知”( as far as I know), “有消息 说” (it is reported that). They are also used to describe the degree of truthfulness of the information, i.e., “大概” (perhaps) and “应该” (may), and show the degree of obscurity, i.e., “只是” (just), “至少” (at least), “大都” (most), and “很” (very). Moreover, they can express speakers' conjectures or opinions. Thus, vagueness is used to enhance liar's linguistic uncertainty and make it impossible for the receiver to get accurate information.

(2) Generality: Generality means generalized words (i.e., friends, and a good relationship), which contain more than one meaning and can be referred to different objects. As specific words, which have more connotative meaning and less denotative meaning, don't require much effort to infer the meaning, general words, which carry multiple meanings, are to be frequently found in deceptive statements. Using many generalized words is evidence of how the deceptive speaker attempts to obscure his statements by providing a less precise description of details. In this way, he conceals what he does not want to be known (Johnson \& Raye, 1981; Scornig, 1989). Thus, generality performs the same function as vagueness, making the information inaccurate.

\subsubsection{Falsification}

(1) References to the other: References to the other refer to the sub-strategy of using third person (singular or plural) when describing an event, whereby the speaker renders himself passive or disappears from the description of the event, and thus he bears no responsibility for the results (Dilmon, 2008). Swol, Braun and Malhotra (2012) found that deceptive speakers used a high percentage of third-person pronouns. Frequenter use of verbs in the third person and minimal use of verbs in the first person in deceptive statements also support the efficiency of this indicator. Consequently, it is a way of falsifying the fact to avoid responsibility.

(2) Intensifiers: Intensifier is a linguistic term for a modifier that makes no contribution to the propositional meaning of a clause but serves to enhance and give additional emotional context to the word it modifies. Intensifiers are confirmed as one type of deception indicators by Yang's research (2012), which is based on Chinese data. Unlike vagueness which makes any possible incriminating behaviors uncertain, intensifiers are used to increase the credibility of the words, i.e., definitely, absolutely, one hundred percent sure, even, very. Furthermore, simile, rhetorical question and repetition are also regarded as intensifiers.

\subsubsection{Distortion}

(1) Minimizing markers: testified as a linguistic indicator, minimizing markers can mitigate the deceptive speaker's role in an event (Dilmon, 2008). Like exaggeration which amplifies the effect, minimizing markers can distort the whole fact by slightly changing the content of the story.

(2) Formulaic expressions: Formulaic expressions is a linguistic term for verbal expressions that are fixed in form, often non-literal in meaning with attitudinal nuances, and closely related to communicative-pragmatic context. Previous research has verified formulaic expressions in deceptive statements (Dilmon, 2008). Cognitive load is an important predictor of formulaic language. Bedwill et al. (2010) found that deceptive statements contain less linguistic complexity because cognitive load is too heavy for deceptive speakers to take advantage of enough cognitive resources to make up a reasonable explanation. In this way, formulaic expressions, which require less cognitive activity, can help liars make up an explanation in a short time and make their wrongdoings seemingly reasonable. 


\section{Linguistic Analysis}

This section will analyze each linguistic deception indicator in seven cases, and explore how linguistic deception indicators operate on DDSA and what motivates DSA.

\subsection{Concealment}

\subsubsection{Vagueness}

As a linguistic deception indicator of concealment, vagueness is used by defendants to withhold important information and protect themselves from punishment.

Extract 1 (Note: $\mathrm{J}=$ Judge, $\mathrm{Pr}=$ Prosecutor, $\mathrm{Dr}=$ Defender, $\mathrm{Dt}=$ Defendant)

Pr: 第三宗事实我们指控你 03 年到 06 年担任 $\mathrm{xx}$ 市常务副市长期间为黄 $\mathrm{xx}$ 谋取利益, 收受他的 440 万港 币。有没有这个事实?

For the third fact, we charge that you received 4.4 million HK dollars from Huang and obtained benefits from him when you were the executive deputy mayor of xx city during 2003 to 2006. Is it true?

$D t$ : 我印象中黄 $\mathrm{xx}$ 没有找过我, 我没有什么事情帮过他。

In my impression, Huang didn't ask me for help, and I didn't help him.

(quoted from case A1)

Extract 2

Pr: 有没有给他项目上的帮助啊！

Did you help him with the project?

Dt: 应该没有。也是我职责所在嘛, 就提了个建议。

Probably not. It is my duty and I just give some advice.

(quoted from case A1)

Extract 3

Pr: 后来你们是什么时候商定好价格和数量的?

When did you agree on the price and quantities later on?

$\mathrm{Dt}$ : 没有商定好价格和数量。

We didn't agree on the price and quantities.

$\operatorname{Pr}$ : 那你怎么知道他一下要这么多的。什么都没有商量? 他就让你买, 你就给他买回来。数额没有商量, 价格也没有商量?

How did you know that he needed such a large quantity? You didn't negotiate? You bought for him as he told you to buy without knowing exact quantity and price?

Dt: 就说见了面再说嘛。

We just said it would be negotiated when we met.

Pr: 数量和价格都没有商量。你怎么敢买这么多。以这样的价钱, 如果他不需要的话, 你怎么处理, 恩? 请你如实地向法庭回答。

How could you buy such a large quantity at this price before agreeing on the exact quantities and price? How would you deal with them if he doesn't need? Emm? Please tell the truth to the court.

$D t$ : 当时电话里完了大致说了要这么多。

He mentioned the quantities roughly on the phone.

Pr: 要多少?

How much?

Dt: 1 千克。

One kilo.

(quoted from B1)

In extract 1, by saying “我印象中” (in my impression), the defendant expects to avoid answering the prosecutor's question. As he neither admits the fact nor denies it, the prosecutor fails to get further information. 
It is the same with the use of “应该” (probably/should) in extract 2. “应该”, a modifier to describe the truthfulness of the information, has two different meanings in Chinese. One is the obligation and the other means the inferences and uncertainty of the speaker. Though the defendant denies "the offer of help from another party", such phrase decreases the accuracy of his answer. As vagueness can decrease negative effects, and the defendant can make an excuse for memory failure to escape punishments for being insincere, once the lie is detected. The sentence “也是我职责所在嘛, 就提了个建议” (It is my duty and I just give some advice) provides over-informative information to make Huang's receiving behavior look non-criminal. In extract 5, faced with the prosecutor's question about the exact quantities and price of drugs, the defendant conceals the real trafficking issues through outright denials “没有商定好价格和数量” (didn’t agree on the price and quantity) and vagueness “见了面再说” (it would be negotiated when we met) and “大致” (roughly). However, his explanations are not persuasive and coherent because it is impossible for people to prepare goods well without receiving any money or promise before making a deal. And then the prosecutor tracks the defendant's vague expressions and tries to clarify the vagueness. Finally, the defendant is forced to tell the exact quantity and price.

\subsubsection{Generality}

Liars conceal those details that could be examined and obscure the atmosphere, and thus generality facilitates liars in covering up real causes of their wrongdoings.

\section{Extract 4}

Pr: 那他为什么会帮你装修, 就不想...不结账呢?

Why didn't you give the money when he decorated for you? Did you ever think of settling the payment?

Dt: 因为我和他关系比较好。

We're in a good relationship.

Pr: 关系比较好?

A good relationship?

Dt: 我们是朋友关系。

We are friends.

$\operatorname{Pr}$ : 那朋友也不能说是帮你装修 60 几万就不结?

Being friends doesn't necessarily mean that you don't have to settle decoration fees over 600,000 yuan, does it?

Dt: 他从来没有说不结账, 我也没有说不给他结账。反正就拖在那里没有结账。

He never said that we wouldn't settle the payment, nor did I say that I wouldn't settle the payment. Anyway, the fees remained delayed and unsettled.

(quoted from case A1)

Extract 5

Pr: 你去做这个事情有没有得到什么好处呢?

Did you get any benefits from this matter?

Dt: 没有。

No, I didn't.

Pr: 就说你会不会得到什么好处呢?

I mean, can you get any benefits?

Dt: 没有。

No, I can't.

Pr: 那你为什么要做这个事情呢?

Then why did you do this thing?

Dt: 我跟韦 $\mathrm{xx}$ 是很好的朋友。经常去他那里喝酒, 然后关系又好。他叫我去我就去了。当时去了, 我真 的不知道会有这种事。

Wei and I are good friends. I often go to his home and drink together, and we are in a good relationship. I went there when he asked me to, but I really didn't know that this thing would happen. 
(quoted from case B4)

In case A1, defendant Huang claimed “关系比较好” (in good relationship) and “朋友关系” (we are friends) to explain why he did not pay money back. "Good relationship" can't explain the degree of their relationship without more facts showing their intimacy. "Friends" can mean sincere guys or people who are interrelated with interests. The defendant wants to make use of this intimate relationship to make his behavior reasonable, hiding interest transaction between him and the briber. However, this excuse is not persuasive. Considering Chinese social context, it is impossible for the creditor not to get such a large amount of money (over 600,000 yuan) back, no matter how intimate they are.

In case B4 of the drug transportation the defendant denied receiving benefits. He claimed that he did the deal for friendship, without actively participating in the drug transportation and nor consciously knowing the intention of doing this thing. However, though he wanted to conceal his active role in this case and show his innocence by providing the excessive information, the judge took him as complicated in the drug transportation case based on the cell phone record, other defendants' statements and some other evidence. The defendant admitted his crime in the final statement and pleaded for forgiveness when he found that it is useless to resort to chicanery.

\subsection{Falsification}

\subsubsection{References to the Other}

Liars are prone to conceal his act of fabrication by emphasizing others' role in the event and using references to the other to "distance themselves from the situation described to make himself a merely supportive player" (Dilmon, 2008).

Extract 6

Pr：你儿子有没有还给他?

Did your son pay him back?

Dt: 也没有。他说等我儿子公司发展以后再还。

No. He said that we would paid back after my son's company developed well.

Pr: 03 年到现在案发, 十几年都没有还给他?

You didn’t pay back after over ten years, from 2003 to the time when your crime was found

Dt: 恩。

Yes.

(quoted from A1)

Extract 7

Pr: 被告人曹 $\mathrm{x}$, 这 14 万元你认为全都是借的, 那么这 14 万元你归还过没有?

Defendant Cao, you think that 140,000 yuan is borrowed, and then did you pay the money back?

$\mathrm{Dt}$ : 我跟他说过。他起房子的时候, 我跟他说, 你起房子要是需要钱, 跟我讲, 我借都要借来还你。(...) 他说不忙用 $(\ldots)$ 所以这个钱, 跟他说过几次, 他说不忙用, 我就没还他。

I told him, he should tell me if he was in need of money when he was going to build his house I said that, if he really needed the money, informed me and I would rather borrow the money to pay him back...... He said he didn't need money badly......so for this money, I told him several times, but he said he didn't need, so I didn't pay back.

(quoted from case A3)

Extract 8

Dr: 刚才公诉人员在讯问你的时候, 你说到王 $\mathrm{xx}$ 这笔借款你是忘了归还, 你是一直忘了归还还是有过归 还的行为, 你能如实陈述一下吗?

Just now, when the prosecutor asked you, you mentioned this loan. Did you forget to pay back or have you ever paid back? Can you tell us truthfully?

$\mathrm{Dt}$ : 当时跟王 $\mathrm{xx}$ 借钱的时候, 我就跟他说过为什么跟他借钱, 是因为一个是当时交房款房产商急着要交 钱。另外呢, 我的现金不够, 因为现金当时是买了理财了, 银行大家都知道, 银行那个理财不让提前支 付, 我就跟王 $\mathrm{xx}$ 借了, 我说借 50 万, 等我的理财到期了还给他。他就同意了, 因为他手里正好有钱...... 然后我就把他约出来, 我说把钱还给他, 我说我这个理财到期了, 因为买理财不是很长时间, 后来他提 


\section{出, 他说不着急, 说你要有急着用, 反正我也不......不急着去花, 就这样, 当时就没有给他。}

When I borrowed money from Wang, I explained the reason why I borrowed from him. One reason is that I need pay for the house. In addition, I didn't have enough cash because I bought money management products. As known to all, the bank doesn't pay in advance. So I borrowed from Wang. I said that I borrowed 500,000 yuan and would pay the money back after my money management products are expired. He agreed because he had money in hand at that time...... then I made an appointment with him, and told him that I would pay the money back to him, for my money management products became due, and I didn't buy money management products for a long time. Then he mentioned it, and he said that it was not urgent for him to use the money, and I could use it if I needed; however, he didn't need it badly. Therefore, I didn't pay the money back to him.

(quoted from case A2)

\section{Extract 9}

Dr：交给杨某 2 哈。然后交给杨某 2 后，你们商量过怎么来分这 10 万块钱没得？

Giving to Yang2? After giving to Yang2, did you agree on how to distribute the 10,000 yuan?

$\mathrm{Dt}$ :被告: 没有。都是领导安排的。

No, leaders managed all this.

(quoted from case A3)

Extract 10

Pr: 你们回来的时候为什么不一起回来呢, 要错开一段距离。为什么? 你是不是在前面探路?

Why did you drive in front of them with a distance rather than come back together? Why? Did you intend to observe the situations before them?

Dt: 韦 $\mathrm{xx}$ 叫我开车到哪里, 我就到哪里。

I drive according to Wei's instructions.

(quoted from case B4)

From extracts 6, 7 and 8, we can see that in three bribery cases A1, A2 and A3, defendants claim that the money received is borrowed. And the question is that such a large amount of money is "borrowed" without a receipt. When explaining why they didn't pay back, they referred to the briber who is not in need of money. Thus, it is "the briber" who refuses to receive the money and they distance themselves from the responsibility. In extract 9 , the defendant, Cao, in case A3, was accused of receiving and sharing bribes 200,000 RMB with other two people whom Cao called leaders. Cao denied that he negotiated with the leader about how to share bribes and he just listened to leaders' instructions. According to the judgment, Yang 1 and Yang 2 (the two leaders) demanded bribes from the person in charge in a project and Cao carried out the action of receiving and allocating bribes after negotiating with the two leaders. The defendant in extract 10 made an excuse that he transported drugs for he had a good relationship with Wei (see extract 5) and he didn't know that the transported goods were drugs. When questioned by the procurator, the defendant put all the responsibility to Wei and denied his active role in drug transporting. By referencing to others, those defendants made explanations about their wrongdoings, distanced themselves from responsibility and finally made up a new story, denying their active participation. If such falsifications were not identified when objective evidence were insufficient, the judge might accept the advice of defenders, and the defendants might avoid punishment.

\subsubsection{Intensifiers}

Use of an intensifier subtly suggests to the receiver what emotion the liar is experiencing, and helps liars make up a story.

\section{Extract 11}

Dt: 好, 审判长。那个她在农行的账号卡号, 我可以说, 负责地说百分之百地我没有给她转过一次一分 钱。

OK, judge. For her card of Agricultural Bank of China, I can say with responsibility and I am one hundred percent sure that I didn't transfer one cent to her card, not for once.

$\mathrm{J}$ : 你的卡在谁手里? 是谁操纵你的卡?

Where is your card? And who is in charge of it? 
Dt: 我的卡, 我自己的, 我从来没有用过她的卡。我在这百分之百地说, 他们绝对, 包括检察官他们根 本没去查过。

My card is on my hand, and I have never used her card. I can say here that I am one hundred percent sure that, they, including prosecutors, have never investigated, definitely not.

$\mathrm{J}$ : 那为什么会有这个转账?

Then why is there a transfer record?

Dt: 那, 审判长, 绝对是他乱说的。

Judge, it is definitely he that makes up.

$\mathrm{J}$ : 她有你的卡吗? 这个是银行交易的明细, 是一个客观证据。

Did she have your card? This is a record of bank transfer, and it is a piece of objective evidence.

$\mathrm{Dt}$ : 这个, 审判长, 我绝对, 百分之百没有给她转过账。如果他把单子打出来, 说多少号转的, 我马上

认。但是绝对他查都没有查, 只是凭王 $\mathrm{xx}$ 一个人的。王 $\mathrm{xx}$ 一个人说我给她转账, 那是不可能。

Emm, judge, I have definitely never transferred to her. I am one hundred percent sure. If the prosecutor hade the copy and showed the exact date of transfer, I would admit immediately. But he has definitely not investigated and just heard what Wang said. Wang said she transferred to me. It is impossible!

$\mathrm{J}$ : 这里是有银行的证据的。

Here is the evidence of bank record.

Dt: 那个证据绝对不是我的卡转的。请你看清楚, 这个上面如果是赖 $\mathrm{xx}$ 的卡给她转的钱。

It is definitely not transferred through my card. Please look through it carefully whether it is transferred from my card or not.

$\mathrm{J}$ : 你这样解释就算了。

If you explain like this, then let it go.

(quoted from the case B2)

\section{Extract 12}

Pr：你实事求实地讲，你看没看见朱 $\mathrm{xx}$ 和那个缅甸女人进行毒品交易？

Please tell the truth. Did you find that Zhu did drug business with that Myanmar woman?

$D t$ : 我确实没有看见。

I really didn't notice that.

Pr: 没看见?

You didn't notice that, did you?

Dt: 对。

No, I didn't.

Pr: 所购买的东西放在哪儿了, 你知道吗?

Where were the goods? Do you know?

Dt: 我不知道。

I don't know.

Pr: 有人往你包里放东西, 你知道吗?

Did you know that someone was putting something in your bag?

Dt: 我不知道。

I didn't know.

Pr: 你觉得你这种解释可信吗?

Do you think that your explanation is credible?

Dt: 但我说的是实话。

But what I said is true. 
$\operatorname{Pr}$ ：你实事求是地讲，在整个过程当中，你是否已经怀疑或者已经意识到她们是在做毒品生意？

Please tell the truth. During the whole process, did you suspect or recognize that they were doing drug business.

Dt: 我从来不会怀疑我的妈妈会去做犯法的事情。

I never doubted that my mother would do something illegal.

(quoted from the case B3)

In the case B2, faced with objective evidence of bank transfer record, the defendant just repeats intensifiers “百 分之百” (one hundred percent sure) and “绝对 (definitely)” without substantive content to show his innocence. He even blames the prosecutor for not investigating this case deeply but just hearing another defendant's words. Repetition of intensifiers shows the anxiety of the defendant. He can't make up a reasonable explanation and provide more details, instead just repeats some intensifiers which he thinks may obtain the judge's trust.

In case B4, the defendant doesn't repeat intensifiers but uses “确实” (really ) to emphasize that she doesn't notice the scene of drug trafficking and “从来不会” (never) to show her trust to her mother, making it seemingly reasonable that she didn't realize that it is a drug trafficking when her mother was doing business with a stranger. However, her descriptions about what she was doing at that time are contradictory with those of another defendant at the scene. She says that she was using her mobile phone while another defendant at the scene states that she was reading a book. Moreover, her own statements in the investigation part shows that she asked what her mother was doing and asked her to give up drug trafficking. In the end, the judge confirms her role in this drug trafficking case and sentences her to eight-years in prison.

\subsection{Distortion}

\subsubsection{Formulaic Expressions}

When liars are required to answer questions in a short time without causing suspicion, they are inclined to use formulaic expressions to make their wrongdoing seemingly rational or unserious.

Extract 13

Pr: 有没有给他一些项目上的帮助?

Did you help him on the projects?

Dt: 应该没有。

Perhaps not.

Pr: 没有?

No?

Dt: 他主要有一个, 他们 $\mathrm{xx}$ 区有个 $\mathrm{xx}$ 镇是革命老区......后来我考虑老区, 因为老区办的副主任找我, 我 就想作为水利厅长接见 $\mathrm{xx}$ 饮水安全也是我职责所在嘛, 后来我们同意, 提了个意见给财政厅, 给这个老 区, 给这个村, 补了十五万块钱。就这么一件事情。

The xx Town in xx District is an old revolutionary base area...... their deputy director asked me for help. I think it is my responsibility to deal with the safety of water resources as the director of Water Resources Department. Then we agreed and gave a suggestion to the Financial Department, allocating this old base areas 150,000 yuan, that's all.

(quoted from A1)

Extract 14

Pr: 那有没有给他帮助过呀。在职务上提拔?

Did you help him? Did you help him with job promotion?

$\mathrm{Dt}$ : 没有。因为设计院是我们水利厅的下属单位。我支持这个单位也是我的职责所在啊。

No, I didn't. Because Design Department is the subordinate of our Water Resources Department. Supporting this department is also my duty.

(quoted from A1)

In the bribery cases, the defendants make up reasonable explanations for their help to bribers. “职责所在”(It's my duty/responsibility.) shows that the defendant takes his responsibility and does the right thing. The defendant uses formulaic expressions to distance himself from taking advantage of profession convenience to help others, 
decreasing the possibility of "trading power for money". Furthermore, formulaic expressions can make the behavior seemingly non-criminal by distorting the fact.

\subsubsection{Minimizing Markers}

Scalar implicature suggests that the utterer had the reason for not using a more informative or stronger term on the same scale. Therefore, a liar would choose minimizing markers to minimize his part in the event and thereby weakens his responsibility for what he has done.

\section{Extract 15}

Pr: 房地产开发, 是吧。他在开发房地产项目, 你有没有从中帮助过他?

You are in real estate development, right? Did you help him when he is developing real estate projects?

Dt：招投标、土地招投放我没有帮忙，但是在房地产开发过程当中，我有些协调。

I didn't help him in invitation and submission to tender and land. But I coordinated a little in the process of developing real estate.

Pr: 有协调过? 跟谁打招呼啊?

Coordinated? To whom did you mention that?

$\mathrm{Dt}$ ：当时他这个项目在 $\mathrm{xx}$ 高新区。我和 $\mathrm{xx}$ 高新区的书记主任讲过, 希望他们支持。

His project was in the Advanced and New District of xx city at that time. I just told the secretary of the Advanced and New District and asked for their support.

(quoted from A1)

\section{Extract 16}

Pr:这个项目是不是水利厅的项目?

Is this the project of Water Resources Department?

Dt: 不是。

No.

Pr: 不是, 那是去协调过?

No? Then why did you coordinate?

$\mathrm{Dt}$ : 不是, 也没有去协调过, 就是一起吃饭的时候, 张 $\mathrm{xx}$ 提过, 我也在场。

No. I didn’t coordinate. Just Zhang mentioned the project, and I was there when we had a meal together.

(quoted from A1)

In the case A1, the prosecutor uses the phrase “帮忙” (help) to show that the defendant $\mathrm{H}$ has the intention to take advantage of his profession convenience to help the briber. Faced with the prosecutor's questioning, the defendant mitigates his role in helping the briber by saying “协调”(coordinate) “讲过” (just tell;mention). Moreover, the defendant uses “有些” (a little) as a degree modifier, trying to make his coordinating influence as little as possible. In this way, the defendant distances himself from responsibility by distorting the fact.

In order to demonstrate the overall manifestations of linguistic deception indicators, a summary of indicators is made in table 2 to provide a presentation of them. 
Table 2. Summary of the use of each kind of indicators

\begin{tabular}{|c|c|c|c|c|c|c|c|}
\hline & & Vague-ness & Generality & $\begin{array}{l}\text { References } \\
\text { to the other }\end{array}$ & Intensifiers & $\begin{array}{l}\text { Minimizing } \\
\text { markers }\end{array}$ & $\begin{array}{l}\text { Formulaic } \\
\text { expressions }\end{array}$ \\
\hline \multirow[t]{8}{*}{ A1 } & Extract 1 & 1 & & & & & \\
\hline & Extract 2 & 1 & & & & & 1 \\
\hline & Extract 4 & & 2 & & 1 & & \\
\hline & Extract 6 & & & 1 & & & \\
\hline & Extract 13 & & & & & & 1 \\
\hline & Extract 14 & & & & & & 1 \\
\hline & Extract 15 & & & & & 2 & \\
\hline & Extract 16 & & & & & 1 & \\
\hline A2 & Extract 8 & & & 1 & & & \\
\hline \multirow[t]{2}{*}{ A3 } & Extract 7 & & & 1 & & & \\
\hline & Extract 9 & & & 1 & & & \\
\hline B1 & Extract 3 & 2 & & & & & \\
\hline B2 & Extract 7 & & & & 2 & & \\
\hline B3 & Extract 12 & & & & 3 & & \\
\hline \multirow[t]{3}{*}{ B4 } & Extract 5 & & 2 & & 1 & & \\
\hline & Extract 10 & & & 1 & & & \\
\hline & Total & 4 & 4 & 5 & 7 & 3 & 3 \\
\hline
\end{tabular}

From table 2 we can easily find that "intensifier" occur most frequently ( 7 times), followed by "references to the other" (5 times). Both "vagueness" and "generality" occur 4 times, ranking No.3. The least frequent strategies are "minimizing markers" and "formulaic expressions". The above manifestation of micro-strategies of deception further indicates that concealment and falsification are the principal strategies.

\section{Conclusion}

This study is an empirical and qualitative study based on authentic data in Chinese courtroom context. Linguistic analyses demonstrate the applicability of six linguistic deception markers in the process of DDSA. Those markers are of great value in DDSA for they help us understand how liars tend to achieve deception goals and avoid responsibility.

This research sheds light on data-based studies on DDSA which can expand the linguistic data and build a deception corpus to make deception detection accurate and comprehensible. It is hoped that this research can offer implications for other judicial practices, like police interrogation and prosecutor's questioning. During the interrogation or questioning, the police or the prosecutor should be careful and sensitive to the linguistic deception indicators and plan his or her questioning strategies well.

However, as the same linguistic deception indicator may demonstrate deception, the nervousness of the defendant, or an idiolect, it is necessary to combine details of the case, context of statements and para-linguistic indicators with linguistic indicators to enhance the accuracy of detection. And as for limitations of this study, it is not representative enough to show deception status in Chinese courtroom trials through only seven cases, and civil cases should be collected to test the generality of those linguistic deception indicators. In addition, while this study makes linguistic analyses based on six deception indicators, in-depth interviews with judicial professionals can be made to test the validity of indicator.

\section{Acknowledgements}

The authors gratefully acknowledge the financial support by a research grand from Guangdong Planning Office of philosophy And Social Science (GD12XWW01).

\section{References}

Arcimowicz, B., Cantarero, K., \& Soroko, E. (2015). Motivation and Consequences of Lying. A Qualitative Analysis of Everyday Lying. FQS, 16(3). https://dx.doi.org/10.17169/fqs-16.3.2311

Arciuli, J., Mallard, D., \& Villar, G. (2009). Um, I can tell you're lying: Linguistic markers of deception versus truth-telling in speech. Applied Psycholinguistics, 397-411.

Azizli, N., Atkinson, B. E., Baughman, H. M., Chin, K., Vernon, P. A., Harris, E., \& Veselka, L. (2015). Lies and crimes: Dark Triad, misconduct, and high-stakes deception. Personality and Individual Differences. https://dx.doi.org/10.1016/j.paid.2015.09.034 
Bachenko, J., Fitzpatrick, E., \& Schonwetter, M. (2008). Verification and Implementation of Language-Based Deception Indicators in Civil and Criminal Narratives. Paper presented at the Proceedings of the 22nd International Conference on Computational Linguistics (Cooling 2008). https://doi.org/10.3115/1599081.1599087

Bachler, C. J. (1995). Resume fraud: Lies, omissions and exaggerations. The Personnel Journal, 74, 50-60.

Bedwell, J. S., Gallagher, S., Whitten, S. N., \& Fiore, S. M. (2011). Linguistic correlates of self in deceptive oral autobiographical narratives. Consciousness and Cognition, 20(3), 547-555. https://doi.org/10.1016/j.concog.2010.10.001

Buller, D. B., Burgoon, J. K., White, C. H., \& Ebesu, A. S. (1994). Interpersonal deception VII. Behavioral profiles of falsification, equivocation, and concealment. Journal of Language and Social Psychology. https://doi.org/10.1177/0261927X94134002

Cao, Y. (2009). Production and Interpretation of lies in cognitive context. Journal of Yangtze Normal University, (5), 123-127.

Chen, L., \& Xu, Z. (2013). A pragmatic approach to litigant's deception strategies in civil cases. Journal of Yili Normal University, (2), 85-90.

Dilmon, R. (2008). Between thinking and speaking-Linguistic tools for detecting a fabrication. Journal of Pragmatics, 41, 1152-1170. https://doi.org/10.1016/j.pragma.2008.09.032

Dulaney, J., \& Earl, F. (1982). Changes in language behavior as a function of veracity. Human Communication Research, (9), 75-82. https://doi.org/10.1111/j.1468-2958.1982.tb00684.x

Ekman, P. (1985). Telling lies: Clues to deceit in the marketplace, politics, and marriage. New York: Norton.

Galasinski, D. (2000). The Language of Deception- A Discourse Analytical Study. Thousand Oaks, CA: Sage.

Goffman, E. (1959). The presentation of self in everyday life. Doubleday.

Granhag, P. A., \& Stromwall, L. A. (2004). The Detection of Deception in Forensic Contexts. Cambridge: Cambridge University Press. https://doi.org/10.1017/CBO9780511490071

Gylfason, H. F., Halldorsson, F., \& Kristinsson, K. (2016). Personality in Gneezy's cheap talk game: The interaction between Honesty-Humility and Extraversion in predicting deceptive behavior. Personality and Individual Differences, 96, 222-226. https://doi.org/10.1016/j.paid.2016.02.075

He, Z. R., \& Zhang, S. L. (2004). Deception as a pragmatic strategy: an adaptation-based approach. Journal of Foreign Languages, (6), 25-31.

Johnson, M. K., \& Raye, C. L. (1981). Reality Monitering. Psychology Review, (88), 67-85. https://doi.org/10.1037/0033-295X.88.1.67

Lindskold, S., \& Walters, P. S. (1983). Categories of acceptability of lies. The Journal of Social Psychology, 120 , 129-136. https://doi.org/10.1080/00224545.1983.9712018

Niesten, I. J. M., Nentjes, L., Merckelbach, H., \& Bernstein, D. P. (2015). Antisocial features and "faking bad": A critical note. International Journal of Law and Psychiatry, 41, 34-42. https://doi.org/10.1016/j.ijlp.2015.03.005

Santibáñez, C. (2017). Strategically wrong: On the relationship between generalized deception and persuasive behaviour. Journal of Pragmatics, 114, 16-31. https://doi.org/10.1016/j.pragma.2017.04.001

Sorning, K. (1989). Some remarks on linguistic strategies of persuasion. In Language Power and Ideology (pp. 95-114). Amsterdam: John Benjamins. https://doi.org/10.1075/ct.7.09sor

Utz. (2005). Types of Deception and Underlying Motivation. Social Science Computer Review, 23, 49-56. https://doi.org/10.1177/0894439304271534

Van Swol, L. M., \& Braun, M. T. (2014). Channel Choice, Justification of Deception and Detection. Journal of Communication, (64), 1139-1159. https://doi.org/10.1111/jcom.12125

Van Swol, L. M., Braun, M. T., \& Malhotra, D. (2012). Evidence for the Pinocchio Effect: Linguistic Differences Between Lies, Deception by Omissions, and Truths. Discourse Processes, 79-106. https://doi.org/10.1080/0163853X.2011.633331

Vrij, A. (2008). Detecting lies and deceit: Pitfalls and opportunities (2nd ed.). Chichester, UK: Wiley.

Yang, F. W. (2012). Lie detection. Bei Jing: The Commercial Press. 
Zhang, L. X. (2008). Anaysis of lie cognitive operation. The Journal of English Studies, (2), 15-19.

\section{Notes}

Note 1. Chinese Courtroom Trials Online (http://tingshen.court.gov.cn) is a website providing the public with trial videos of 520 courts to improve the efficiency and accuracy of the court.

Note 2. Trial Scene (http:tv.cctv.com/lm/tsxc/) is a program of CCTV 12, recording the proceeding of trials. Details of litigants help the public understand the case comprehensively.

\section{Appendix}

\section{Case Descriptions}

Linguistic data of DSA in this study are transcribed from seven cases. The letter A stands for bribery cases, B means cases related to drugs, i.e., drug trafficking and drug transporting.

\section{Case A1}

The defendant $\mathrm{H}$ was accused of receiving bribes of 80 million in 27 issues, relative to the development of real estate, the contract of water resources project, the job promotion, the change of job, etc. Huang admitted that basic facts are true, but made excuses and shirked the responsibility in the cross-examination process.

\section{Case A2}

Defendant $\mathrm{S}$ was once the leader of Examination Department in xx City. He was accused of receiving bribes in 5 issues, one of which is that he asked $\mathrm{W}$ to give him 500,000 yuan for S pays for the new house. W's company signed a contract with S's department. In this issue, the court doesn't accept the defender's opinion that S's behavior is a kind of borrowing behavior among individual persons, not being regarded as a bribery behavior. According to the judgment, normal borrowing behavior will reach agreement on the time, method and interests of paying back. But asking for bribes in the name of borrowing doesn't appeal to the above criteria or achieve the promises. In this case, $\mathrm{S}$ asks $\mathrm{W}$ to lend him 500,000 yuan without any procedures or agreed period of paying back. Moreover, S doesn't pay back or show willing to pay back within more than two years when he has the capability to do so. S's behavior is recognized as asking for bribes and s receives a heavier punishment according to the court's opinion.

\section{Case A3}

The defendant $\mathrm{C}$, once the member of party committee and military minister of $\mathrm{xx}$ Town, $\mathrm{xx}$ County, was mainly responsible for land acquisition and relocation. He was accused of taking advantage of his job convenience to get 354,784 yuan of land expenses with other national staffs and he actually got 300,000 yuan. He asked for and received bribes alone or with others of 501,800 yuan, actually getting 331,800 yuan. The court confirmed C's crime for asking his two subordinates $\mathrm{L}$ and $\mathrm{Z}$ to make fake documents of a homestead to get money, borrowing 140, 000 yuan from $\mathrm{Lu}$ and the joint crime of receiving 100,000 yuan with his two leaders, Y 1 and Y 2.

\section{Case B1}

$\mathrm{H}$ was accused of a joint crime of drug trafficking with J, Y, Z, Y. H bought drugs from J who entrusted $\mathrm{Y}$ to buy drugs in xx city. Neither of them admits committing this crime. In extract 3, the defendant has to tell the quantities and prices of drugs after failing to conceal the fact by using vagueness.

Case B2

Defendant $\mathrm{L}$ was accused of drug transporting with $\mathrm{W}$. According to the prosecutor, $\mathrm{W}$ carried drugs on the plane under the threat of L. Lai denied this behavior and claimed that he sent $\mathrm{W}$ to the airport just because they were friends. In extract 11, the defendant just repeats with intensifier to show his innocence when faced with the objective evidence.

\section{Case B3}

This is a joint crime in which $\mathrm{Z}$ and her cousin $\mathrm{Z}$ 2, her daughter $\mathrm{Y}$ and her other relatives were accused of drug trafficking. Extract 12 is the questioning to $Y$. Both $Z$ and $Z 2$ claimed that $Y$ didn't know what they were doing. In the end, the judge confirmed her role in this drug trafficking case and sentenced her an eight-year e imprisonment. 


\section{Case B4}

This is a joint crime in which L, W and $\mathrm{H}$ were accused of transporting drugs for the person they called "Boss" from $\mathrm{xx}$ city to $\mathrm{xx}$ county. According to the prosecutor, on the way to $\mathrm{xx}$ county, $\mathrm{W}$ and $\mathrm{H}$ were responsible for the observation of police inspection while $\mathrm{L}$ carried drugs of 11 pieces of heroin. $\mathrm{H}$ denied his active participation in the crime, but the judge confirmed his role and sentenced him as the criminal of drug transporting.

\section{Copyrights}

Copyright for this article is retained by the author, with first publication rights granted to the journal.

This is an open-access article distributed under the terms and conditions of the Creative Commons Attribution license (http://creativecommons.org/licenses/by/4.0/). 